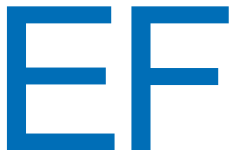

\title{
(1) Water pricing and allocation
}

\section{Agriculture, industry and cities are placing ever greater demands on water resources.}

Implementing policies that encourage efficient water use, such as water allocation or pricing programmes that reflect increasing water scarcity, will motivate farmers and other water users to improve their management practices. Such efforts, in conjunction with programmes that enhance access to water by the poor, are essential to ensuring that household and global food security goals are achieved.

\section{Key messages}

- Agriculture is the largest water-dependent sector, receiving up to $70 \%$ of freshwater withdrawals in many countries.

- Agricultural and irrigation subsidies often give the wrong signals regarding water scarcity, thus encouraging farmers to apply too much irrigation water and withdraw excessive amounts of groundwater.

- In many places, water allocations might be easier to implement than water pricing, particularly in the near-term. However, public agencies in many areas should take a long-term view toward establishing the institutions and investing in the infrastructure needed to support effective water pricing programmes.

\section{The context}

Many countries have a long history of providing subsidized irrigation water to farmers. This made sense when governments first began constructing large-scale irrigation schemes because their aims were to expand economies and develop rural areas. However, with increasing urbanization, industrial development and greater recognition that the environment is also a water user and provides valuable services, competing demands for water have increased substantially. In many areas, societal preferences regarding water allocation have changed markedly since the time when irrigation projects were first developed.

Agriculture is the largest consumer of water, using up to $70 \%$ of the developed freshwater resources in many countries. Continuing to subsidize water supplies can give farmers the false impression that water is plentiful. New approaches are needed so that all water users recognize the scarcity value of water in each setting, and they are motivated to use water resources efficiently. 


\section{IWMI's position on the economics of water}

Water plays many roles in households, on farms, in commerce and in industries. Farmers use water to grow crops, while businesses use water for a range of processes from cooling equipment to washing manufactured items. Whether water is used as an input to produce something or is consumed in a household, there is an element of economics involved. The value of water in any use varies with location, season and water scarcity conditions. To fully understand water use decisions, we must study the economic sectors in which people live and work. We must also understand how macroeconomic policies, and the cost and availability of other inputs, influence decisions taken within those sectors. Economists have much to contribute in the study of water use, allocation and management.

\section{Actions needed}

Charging for water is one way of making people more aware of its value and encouraging them to use it wisely. In developed countries, the extra demands placed on water supplies have come from industry, municipal areas, recreation and the environment. Here, rising demand is linked to increasing wealth. As incomes rise, people expect their environment to be cleaner, with unpolluted rivers and lakes. The struggle between agriculture and other sectors for water becomes more intense. With the public less willing to subsidize farmers and with competing demands on public budgets, public agencies are beginning to charge higher prices for irrigation water.

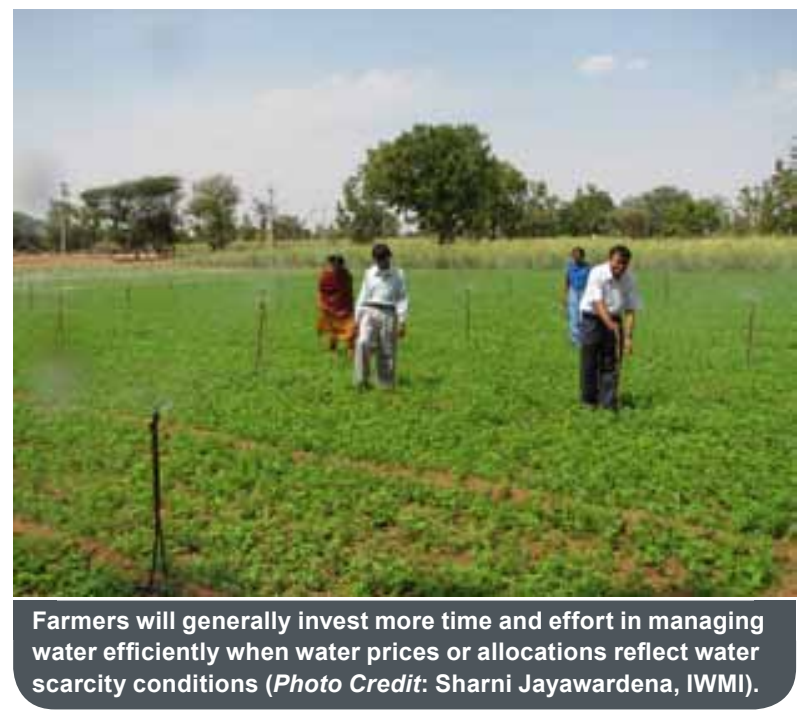

In the developing world, where many more people rely on farming for their livelihoods, governments have been reluctant to introduce or increase charges for irrigation water. In India, for example, public support for agriculture comprises a notable portion of government expenditures, with much of that support going to subsidize energy that farmers use to pump groundwater. Farmers have become accustomed to the subsidies and, within such a broad-based democracy, politicians risk losing power if they introduce policies that displease the farmers. With subsidies giving the wrong signals regarding water scarcity, farmers are over-pumping groundwater, placing undue pressure on aquifers and causing problems for downstream users.

Another challenge regarding water pricing or allocation is that effective methods are needed for measuring water volumes. While this is relatively straightforward in the West, where there are large farm sizes and modernized irrigation systems, it is much harder in developing countries. Farm sizes can be as small as a quarter of a hectare, irrigation is often decentralized, and water reaches farm fields via gravity flow through small, irregular ditches. Institutions are often less well developed and people are not accustomed to paying for resources. In such instances, water allocations might be easier to implement than water pricing. Allocations, if determined and enforced appropriately, convey the same message regarding water scarcity and provide the same incentive to use water efficiently.

\section{How IWMI can help}

The Jyotigram project in India demonstrates how energy pricing policy can be an effective instrument in allocating water subsidies. The State of Gujarat faced the dual problem of a bankrupt electricity utility and depleted groundwater resources, following the introduction of electricity subsidies to farmers from around 1970. The subsidies enabled farmers to pump groundwater from ever-increasing depths at no additional cost. The Asian Development Bank and World Bank both indicated that state governments should eliminate the electricity subsidies. When some states tried to do so, farmers formed powerful lobbies and several chief ministers lost their positions. A different solution was clearly required.

IWMI researchers suggested that governments should separate the power cables carrying electricity to farmers from those supplying other rural users, such as domestic households and industries. The goal was to provide farmers with a high-quality power supply for a set 


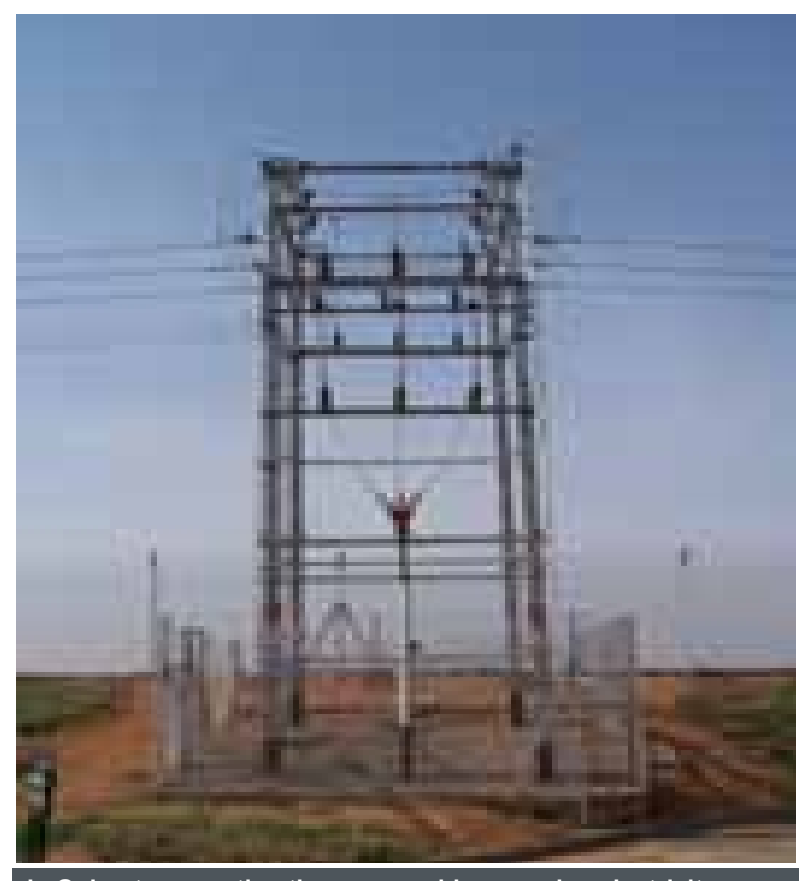

In Gujarat, separating the power cables carrying electricity to farmers from those supplying other rural users, such as domestic households and industries, had positive impacts much greater than anticipated. Photo Credit: Terry Clayton, IWMI.

number of hours each day at a price they could afford. Eventually, Gujarat decided to take up this plan. A study conducted afterwards found the positive impacts to be much greater than anticipated. Prior to the policy change, farmers had been reducing the electricity available to rural communities by overusing power for irrigation. After the cables were separated, rural households, schools and industries had a much higherquality power supply, which in turn greatly boosted the well being of individuals.

Another example of a policy distortion that complicates allocating or charging for water is the fixed pricing of agricultural produce. For example, farmers in Egypt must sell the cotton they produce to the government for a set price that is less than the world market price. The government says it does not need to charge for water because it obtains revenue from cotton sales. Farmers in Uzbekistan face a similar situation. Irrigation water is free, but they must sell their cotton to the government for prices substantially below market levels. Because water is free, farmers have little incentive to use it efficiently. "What we'd like to see is the removal of policy distortions, thus allowing input and output prices to reflect scarcity conditions and enabling farmers to choose the crops they grow, select their irrigation methods, and decide how much water they use," says Dennis Wichelns, Principal Economist, based at IWMI's headquarters in Colombo, Sri Lanka.
"Making such changes requires time. It is not possible to begin charging for water or allocating the resource more carefully overnight. However it is possible and essential - to take a medium- or long-term view toward improving water-use efficiency. For example, a government might determine that it wishes to begin pricing or allocating water volumetrically within five years," he explains. "The government can then begin changing mind-sets and developing the physical and institutional enhancements needed to support water pricing and allocation."

Changing mind-sets is critical to implementing such policies. Farmers, water agency staff members, and consumers must realize that they will be better-off with water pricing or allocation. For example, charging for water would enable new investments in irrigation infrastructure that can make water supplies more reliable. Such efforts require substantial groundwork in talking to policymakers, meeting with water user associations and explaining programme benefits to canal managers. Any changes must also ensure that the most disadvantaged groups are not harmed further. Part of IWMI's work in this area involves working closely with farmers and with state-level and local water-resource managers to inform them of opportunities, and to gain their trust regarding new policies and programmes.

IWMI is well placed to lead discussions on water policy and economics, as it has specialists in the relevant disciplines and considerable experience in the field across the developing world. Many IWMI scientists in its regional offices in Africa and Asia speak local languages and spend $50 \%$ or more of their time working closely with water providers and users. They have academic experience coupled with practical knowledge about what works and doesn't work, given local socioeconomic, cultural and political conditions.

"Nearly all water use in the world today is linked in some manner to economics," says Wichelns. "To feed the world's growing population we need to increase our investments in existing and new irrigation infrastructure. This will require good policies regarding economics and finance. At the micro-level we need to encourage farmers to be more efficient and productive with the water they have. At the macro-level, we must ensure that national policies regarding input and output prices, exchange rates, and the availability of farm credit and technical assistance also support agricultural development. Put simply, it's about having the right economic incentives in place, with appropriate safeguards to ensure that the poor retain their access to the land and water resources that are so critical to maintaining their livelihoods and ensuring food security." 


\section{Source}

This Water Issue Brief is based on the following publications:

Abernethy, C. L.; Sally, H.; Lonsway, K.; Maman, C. 2000. Farmer-based financing of operations in the Niger Valley irrigation schemes. Colombo, Sri Lanka: International Water Management Institute (IWMI). 41p. (IWMI Research Report 037)

IWMI (International Water Management Institute). 2007. Does food trade save water? The potential role of food trade in water scarcity mitigation. Colombo, Sri Lanka: International Water Management Institute (IWMI). 7p. (IWMI Water Policy Briefing 025)

International Water Management Institute, IWMI-TATA Water Policy Program. 2003. The energy-irrigation nexus. Vallabh Vidyanagar, Gujarat, India: International Water Management Institute (IWMI). 6p. (IWMI Water Policy Briefing 010)

Molle, F.; Renwick, M. 2005. Economics and politics of water resources development: Uda Walawe Irrigation Project, Sri Lanka. Colombo, Sri Lanka: International Water Management Institute (IWMI). 74p. (IWMI Research Report 087)

Perry, C. J.; Rock, M.; Seckler, D. 1997. Water as an economic good: a solution, or a problem? Colombo, Sri Lanka: International Irrigation Management Institute (IIMI). 21p. (IWMI Research Report 014 / IIMI Research Report 014)

\section{Related IWMI Publications}

\section{Open access (electronic version freely accessible via the internet)}

Kumar, M. D. 2005. Impact of water prices and volumetric water allocation on water productivity: comparative analysis of well owners, water buyers and shareholders. IWMI-Tata Water Policy Research Highlight, 2005/11:11p.

Liao, Y.; Gao, Z.; Bao, Z.; Huang, Q.; Feng, G.; Xu, D.; Cai, J.; Han, H.; Wu, W. 2008. China's water pricing reforms for irrigation: effectiveness and impact. Colombo, Sri Lanka: International Water Management Institute (IWMI), Comprehensive Assessment Secretariat. 74p. (Comprehensive Assessment of Water Management in Agriculture Discussion Paper 6)

Molle, F.; Berkoff, J. (eds.). 2007. Irrigation water pricing: the gap between theory and practice. Wallingford, UK: CABI. 357p. (Comprehensive Assessment of Water Management in Agriculture Series 4)

Perry, C. J. 2001. Charging for irrigation water: the issues and options, with a case study from Iran. Colombo, Sri Lanka: International Water Management Institute (IWMI). 22p. (IWMI Research Report 052)

Perry, C. J.; Rock, M.; Seckler, D. 1997. Water as an economic good: a solution, or a problem? Colombo, Sri Lanka: International Irrigation Management Institute (IIMI). 21p. (IWMI Research Report 014 / IIMI Research Report 014)

Venot, J-P.; Molle, F.; Hassan, Y. 2007. Irrigated agriculture, water pricing and water savings in the Lower Jordan River Basin (in Jordan). Colombo, Sri Lanka: International Water Management Institute (IWMI) 55p. (Comprehensive Assessment of Water Management in Agriculture Research Report 018)

\section{Citation:}

International Water Management Institute (IWMI). 2010. Water pricing and allocation. Colombo, Sri Lanka: International Water Management Institute (IWMI). 4p. (IWMI Water Issue Brief 6). doi: 10.5337/2010.219

Keywords: water allocation / price policy / irrigation water / electricity supplies

Copyright $\odot 2010$, by IWMI. All rights reserved. IWMI encourages the use of its material provided that the organization is acknowledged and kept informed in all such instances.

Content Contributors: Dennis Wichelns, Principal Economist.

Credits: Managing Editor: Terry Clayton; Editing: Mahen Chandrasoma; Layout: Sumith Fernando

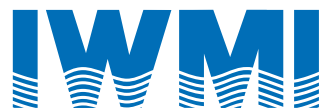

International Water Management

I n s t i t u t e
All IWMI Publications are available online free of charge at www.iwmi.org/Publications Comments and questions are welcome.Please contact us at: IWMI-Publications@cgiar.org Publications Unit, International Water Management Institute, PO Box 2075, Colombo, Sri Lanka Tel: +94 112880000 Fax: +94 112786854

\section{www.iwmi.org}

Improving the management of land and water resources for food, livelihoods and the environment

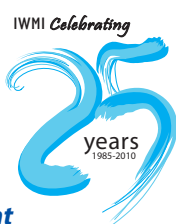

